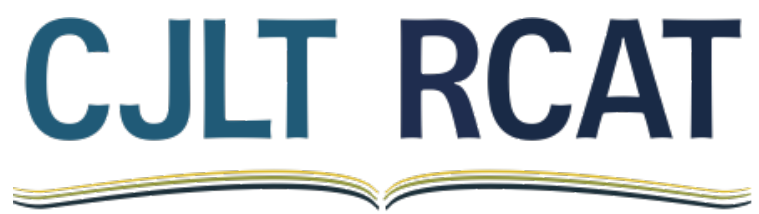

Canadian Journal of Learning and Technology

La Revue canadienne de l'apprentissage et de la technologie

\title{
Reading in the Digital Age: Using Electronic Books as a Teaching Tool for Beginning Readers \\ La lecture à l'ère numérique: I'utilisation de livres électroniques comme outil d'enseignement pour les lecteurs débutants
}

Katia Ciampa, Brock University

\begin{abstract}
Beginning readers' motivation to read and the texts they choose to read impact on their literacy achievement and willingness to engage with reading activities in the primary years of schooling. This study investigated the eBook reading experiences of eight grade 1 students. Eight students were given ten 25-minute sessions with the software programs over 15 weeks. Qualitative data were collected from students, teachers, and parents through questionnaires, interviews, observations and field notes. The results suggest the promise of electronic books in enhancing the reading motivation of beginning readers.
\end{abstract}

\section{Keywords}

Digital reading; early literacy; reading motivation; online; eBooks; constructivism

\section{Résumé}

La motivation des lecteurs débutants et les textes qu'ils choisissent de lire ont un impact sur leur succès en littératie et sur leur volonté de prendre part à des activités de lecture au cours des années du primaire. Cette étude s'est penchée sur les expériences de lecture de livres électroniques de huit élèves de première année. Huit élèves ont reçu 10 séances de 25 minutes avec les logiciels sur une période de 15 semaines. Des données qualitatives ont été recueillies auprès des élèves, des enseignants et des parents par l'entremise de questionnaires, d'entrevues, d'observations et de notes. Les résultats suggèrent que les livres électroniques sont prometteurs pour stimuler la motivation des lecteurs débutants. 


\section{Introduction}

Learning to read proficiently in the primary grades is one of the cornerstones of academic achievement and the foundation for children's later success in school (Strommen \& Mates, 2004; Valleley \& Shriver, 2003). Children who successfully learn to read in the early primary years of school are well prepared to read for learning and for pleasure in the years to come. Thus, primary educators have the profound challenge of making reading a reality for all children.

Much of the research on young children's reading has focused on cognitive aspects such as word recognition and comprehension skills (Guthrie \& Wigfield, 2000). Yet, because reading is such an effortful activity, motivation is a factor in whether children choose to devote their energy to such a task (Deci \& Ryan, 1985). Motivation to read is both the essential element for actively engaging young children in the reading process and a strong predictor of later reading skills (Deci \& Ryan, 1985), and goes beyond time spent reading. Rather, it is reflected in how children think about themselves as readers and how they think about the act of reading and associated language-based activities (Deci \& Ryan, 1985). Increasing reading competence is motivating for students, and increasing motivation leads to more engaged reading time (Guthrie \& Wigfield, 2000). For students who do not master reading skills early in their school years, reading may become a painful experience (Wigfield \& Guthrie, 1997). As a result, they may decline opportunities for practice, putting themselves even further behind successful, motivated readers who may be independently reading as much as three times the amount of text as poor, unmotivated readers (Wigfield \& Guthrie, 1997).

Motivation to read is one of the essential elements for actively engaging children in the reading process and is an important component for all students to be successful in school (Morgan \& Sideridis, 2006; Strommen \& Mates, 2004). Research shows that promoting students' motivation to read can enhance the reading competency of readers (Morgan \& Sideridis, 2006; Sideridis \& Scanlon, 2006; Strommen \& Mates, 2004). Motivated readers read more, have larger vocabularies, use more complex cognitive strategies, and thus become better readers (Krashen, 2009; Krashen \& McQuillan, 2007). When children are motivated to read and to do so without fear of failure, they also tend to excel in reading at or above their grade level (Grimshaw, Dungworth, McKnight, \& Morris, 2007, p. 586). On the other hand, children who struggle with reading and do not read regularly become even weaker readers with each subsequent year (Nelson \& Manset-Williamson, 2006; Valleley \& Shriver, 2003).

Literacy educators and researchers such as Metsala, Wigfield, and McCann (1997) note that aliteracy is becoming a growing phenomenon. Scott (1996) defined aliteracy as a "lack of reading habit especially in capable readers who choose not to read" (p. 195). Aliterates typically suffer from a lack of engagement or intrinsic motivation to read, even when they are capable of successfully comprehending material (Asselin, 2004). Reading for pleasure, which is one of the ultimate goals of learning to read, is less observed among youth, and there has been a steady decline in the amount of leisure time reading as they proceed to the upper grades (Moje, Young, Readence, \& Moore, 2000).

A major step in preventing early reading difficulties and reducing this gap, then, is to ensure that early reading interventions that emphasize one of the three main goals for reading instruction, namely, motivation for reading (Ministry of Education of Ontario, 2003). The vast numbers of readers who move through classrooms unmotivated and uninterested in reading are just as 
troubling as the struggling readers. Many children are quite capable of reading, and do so frequently and with enthusiasm outside of school, and yet, these same youth exhibit poor reading skills and resist reading in the classroom. Children with lower motivation also usually exhibit and sustain poor performance in reading activities (Chapman, Tunmer, \& Prochnow, 2000). One method of improving reading ability and motivation is to make classroom texts more engaging and connected to the outside world (Miller, 2009). Teachers have a pivotal role in helping children to develop and maintain a positive attitude towards learning and to inspire a love of reading, using interesting books that the children want to see, hear, and hold (Miller, 2009). Given the powerful and pervasive influence of the Internet on today's youth, it is not surprising that such online technologies as electronic storybooks (eBooks) have been touted as effective in promoting children's language and literacy skills (Blok, Oostdam, Otter, \& Overmaat, 2002; Castek, Bevans-Mangelson, \& Goldstone, 2006; Korat \& Shamir, 2006; Lefever-Davis \& Pearman, 2005; Plowman \& Stephen, 2003; Valmont, 2000; Van Kleeck, 2003;Wepner \& Ray, 2000). Online children's storybooks have taken traditional oral or print stories, and added multimedia and multisensory features such as animated illustrations, sound effects, and fully digitized audio narration accompanied by highlighting of the text, all of which offer young children and struggling readers interactive storybook choices that they can enjoy reading independently (Alexander \& Jetton, 2003; Castek et al., 2006). To stimulate the children's reading orientation and involvement in reading, electronic storybooks let children activate reading of words, phrases, or pages in any order they want and are typically equipped with sound and animations that are activated by the child (Reinking \& Watkins, 2000). The children can also use a function that allows them to reread/relisten to the highlighted text by clicking on an arrow that repeats the text (Korat \& Shamir, 2006). In this fashion, the children's attention is focused on the relationship between the text and oral reading by the highlighting of written text (de Jong \& Bus, 2002).

Although there is evidence to suggest that the features embedded within eBooks contribute to children's early reading development, further research documenting students' experiences with, attitudes toward, and their motivation for reading these digital texts in the early primary grades are warranted. The purpose of this qualitative study, then, is to explore eight primary-grade students' experiences with eBooks. Specifically, the present study investigates: What are eight grade 1 students' experiences with reading, in general, and more specifically, with eBook reading?

\section{Theoretical Framework}

Constructivism learning theory is defined as the learner's active construction of new knowledge based on his or her prior knowledge and experiences (Dewey, 1916; Kroll, 2004; Piaget, 1973). The conceptualization of the child as passively responding to his or her environment and learning directly through internalization knowledge given by others is rejected by constructivists such as Piaget (1973). Within Bruner's (1960), Piaget's (1973), and Dewey's (1916) constructivist theories, the basis of learning is child-determined exploration and guided discovery rather than direct teaching. Constructivist theory also emphasizes that learning should be authentic, and that learning needs to meet real-life experiences. Thus, the belief for educators in teaching is that reading instruction should be grounded in contexts that are familiar to students. Learning in a familiar context may make learning more personally relevant than decontextualized learning (Hooper \& Rieber, 1995). The constructivist goals of learner control, autonomy support, choice, 
active problem-solving, and use of relevant and authentic texts in beginning reading instruction are preferred to explicit, teacher-directed instruction.

The present paper also drew on the central constructs of motivation in relation to grade 1 students' reading experiences, including (a) intrinsic and extrinsic motivation (Deci \& Ryan, 1985); (b) self-efficacy and competence beliefs for reading (Eccles, 1983); and (c) achievement goal orientations for reading (Malloy, Marinak, \& Gambrell, 2010). From an educational point of view, motivation refers to "the likelihood of choosing one activity over another, as well as the persistence and effort exerted when participating in the chosen activity" (Malloy et al., 2010, p. 2). Motivation has also been recognized as an important aspect and requirement of constructivism and the building of new knowledge (Piaget, 1973).

Students are now immersed in communication technologies such as the Internet (Clark \& Foster, 2005); the future of education, then, depends on our ability to integrate technologies that complement students' out-of-school lives (Scheiter \& Gerjets, 2007). When making a case for reading online eBooks in particular, researchers and educators often use words like choice, interest, control, involvement, stimulation, challenge, and curiosity to capture their motivational and constructivist qualities (Piet, Kommers, \& Dunlap, 1996). Applying the two theoretical stances of constructivism and motivation to this study provided a way of exploring the connections between online constructivist learning tools such as eBooks and grade 1 students' reading motivation.

\section{Review of the Literature}

\section{Foundations of Reading Motivation}

\section{Intrinsic and Extrinsic Motivation}

Deci and Ryan (1985) refer intrinsic motivation to initiating an activity for its own sake because it is interesting and satisfying in itself, as opposed to doing an activity to obtain an external goal or tangible rewards such as stickers (extrinsic motivation). Although there is a fundamental distinction in the motivation literature between intrinsic motivation and extrinsic motivation, and students may be sufficiently motivated for either intrinsic or extrinsic reasons to participate in reading tasks, there is a growing consensus that these two constructs should not be treated as polar opposites (Brophy, 2004). Rather, they often both operate in different situations, and may even form a continuum (Brophy, 2004).

\section{Self-Efficacy for Reading}

Students may choose to participant in one learning activity over another on the basis of how well they expect to do, or their expectancy. According to Eccles (1983), perceptions of expectancy are influenced by the students' sense of competence in completing a specific task successfully. With regard to reading, a review of studies related to self-concept (Chapman \& Tunmer, 2003) found that students' self-concepts develop in response to their early experiences with reading- whether these are perceived as being pleasant and successful, or uncomfortable and difficult. Students who experience early and repeated difficulties with reading may develop a self-concept as a "bad reader," which then influences their expectancy for engaging in other reading tasks. 
In line with this understanding, the major influences on children's reading self-efficacy beliefs are how well they have done on similar tasks or activities and the feedback and encouragement that they receive from others (Das, Schokman-Gates \& Murphy, 1985). Thorndike's (1932) law of effect helps explain the important role of feedback in learning. Thorndike stated that behaviours that lead to satisfaction increased the probability that these same behaviours would occur again under similar circumstances. Similarly, Skinner (1969) advocated for immediate feedback that informs the learner about the adequacy of their responses and also increased the probability that the behaviour will occur in the future. According to McClenaghan and Ward (1987), feedback has two important functions. First, it can motivate students, and second, it can provide information that they can use to correct or improve their learning. If the behaviour is incorrect, the immediate feedback allows the learners to make corrective modifications and prevents continued practice of the incorrect behaviour (McClenaghan \& Ward, 1987). On the other hand, if the behaviour is correct, immediate feedback can motivate students to continue (McClenaghan \& Ward, 1987). The immediacy of feedback on the correctness of student responses has also been found to improve learning and retention (Epstein \& Brosvic, 2002; Epstein et al., 2002). In contrast to the delayed feedback students typically receive when completing comprehension worksheets in class, and as will be further discussed later, the posteBook reading comprehension questions provided child participants with immediate feedback about the accuracy of their answers to each question. The child participants' experiences with these immediate-feedback assessments were examined.

\section{Achievement Goal Orientations for Reading}

Research designed to understand why students choose to learn has been organized into two broad orientations (Malloy et al., 2010). The first orientation contains mastery or learning goals, which occurs when children focus on improvement and mastery of a skill such as reading (Malloy et al., 2010). The second orientation involves ego or performance goals, which occurs when children focus on how well they feel they perform in relation to others (Malloy et al., 2010). When confronted by difficulty (or failure), mastery-oriented children persist, stay focused on the task, and sometimes even use more sophisticated strategies (Malloy et al., 2010). On the other hand, when students with performance-avoidance orientations experience failure, they attribute their failures to lack of ability rather than effort attributions, may develop maladaptive forms of behaviour such as a low level of persistence, and engaging in off-task and disruptive behaviour instead of task-focused behaviour (Covington, 2000; Onatsu-Arvilommi, Nurmi, \& Aunola, 2002). Consequently, these students with performance-avoidance learning strategies have lower levels of reading achievement than intrinsically motivated students (Aunola, Nurmi, Niemi, Lerkkanen, \& Rasku-Puttonen, 2002).

\section{The New Literacy of the Digital Age: the Use of eBooks as a Motivational Tool for Reading}

In the $21^{\text {st }}$ century, the definition of literacy has expanded from traditional notions of reading and writing to include the students' ability to learn, comprehend, and interact with technology (de Jong \& Bus, 2002). As one looks at the interface of technology and literacy, perhaps most potentially rewarding for literacy educators is the role of technology in reading acquisition and instruction, especially for primary grade populations (de Jong \& Bus, 2002). For students in the beginning reading stages, it is even recommended that they use "developmentally appropriate 
information and communication technologies such as the Internet to support and communicate their learning in language" (Ministry of Education of Ontario, 2003, p. 30). Online children's storybooks are one example of how teachers of beginning readers can use such communication technologies to advance the goals of their reading program (Alexander \& Jetton, 2003; Blok et al., 2002; Castek et al., 2006; de Jong \& Bus, 2002; Korat \& Shamir, 2006; Labbo \& Kuhn, 2000; Lefever-Davis \& Pearman, 2005; Wepner \& Ray, 2000). One of the more compelling findings from the research literature on information and communication technologies is that children are highly motivated and interested in the new literacies of the Internet (Reinking \& Watkins, 2000). As illustrated in this review, there is evidence to suggest that the features embedded within electronic storybooks contribute to children's early reading development, further research documenting students' experiences with, attitudes toward, and their motivation for reading these digital texts in the early primary grades are warranted.

However, it is important to note that despite the potential effectiveness of computer-based learning, there are limitations characteristic of studies on this type of instruction. Discussions of uncontrolled effects, including novelty effects, have noted that high levels of motivation and attention are often associated with new activities (Krendl \& Clark, 1994). The criticism of these findings is that is the motivation and attention, inflated by the novelty of the computer application, that account for enhanced learning outcomes and positive attitudes that result (Krendl \& Clark, 1994). The implication of this criticism is that the positive outcomes learning from the new medium, having more positive attitudes about learning will tend to decline as the technology becomes more familiar and its novelty wears off. The concept of the novelty effect has been neglected in research on technology and learning because of the preference for shortterm, small-scale experimental applications of technology (Krendl \& Lieberman, 1988; Krendl \& Clark, 1994). Reliance on short-term applications of computers does not rule out the possible role of novelty effects in accounting for the generally positive results emanating from computer applications. The current study attempted to overcome this limitation by observing the child participants' interactions with the eBooks over an extended period of time (nine months).

\section{Methods}

\section{Participants}

The total sample consisted of eight students (four boys and four girls) aged 5 and 6 years, drawn from two grade 1 classrooms in one elementary school (School 1), and two grade 1 classrooms in the other elementary school (School 2). All participants were English-speaking and of Caucasian descent. Both elementary schools were situated in the same school district in southern Ontario, Canada. In order to protect the participants' identities, pseudonyms were used.

The first teacher participant, Debra, was a certified teacher with 15 years of teaching experience, all of which had been at the primary level. Her first grade classroom consisted of 18 students (8 boys, 10 girls). James and Sally were both enrolled in Debra's grade 1 classroom in School 1. James and Sally were "most comfortable reading very simple predictable books" (Debra, Term 1 report card comment). James was "a very capable student but struggled with focus and being attentive to [reading] tasks" (Debra, Term 2 report card comment). Contrary to James, Sally was labelled by her teacher as a "very quiet student [who] only participated in discussion when asked a direct question" (Debra, Term 1 report card comment). According to her parents, Sally also "enjoyed being read to and sharing books with others" (Parent Questionnaire 1). 
Veronica, a grade 1 teacher employed in School 1, had been teaching for 34 years (18 of which have been within the primary division). Veronica's grade 1 classroom had a total of 19 students (10 boys, 9 girls). John and Christopher were two student participants in Veronica's grade 1 classroom. John was characterized as a "laid back, well-behaved, quiet student" who actively participated in classroom reading activities but was "just not as enthusiastic and keen as Christopher" (Veronica, Interview 1). Unlike John, Christopher seemed "very involved and interested" during reading activities and was "always excited to put his hand up and participate in class discussions" (Veronica, Interview 1).

Jessica taught a grade 1 classroom in School 2. Her class consisted of 19 students (10 girls, 9 boys). Sarah and Christina were two student participants enrolled in School 2 in Jessica's grade 1 classroom. Sarah was a "highly motivated, confident student" (Jessica, Interview 1) who "demonstrated strong independent reading skills," and "was an excellent participant during discussions and reading activities" (Jessica, Term 2 report card comment). Christina was not classified as a hyperactive student, but her attention to directions and questions was limited, and "she often required teacher assistance with most reading and writing activities" (Jessica, Term 1 report card comment).

Tracy was the final grade 1 teacher participant from School 2 with a class size of 19 students (10 boys, 9 girls) and 18 years of teaching experience, all of which were also spent teaching within the primary division. Jaclyn and Mark attended School 2 and were both grade 1 students in Tracy's classroom. Jaclyn was "most comfortable reading simple pattern books" (Tracy, Term 1 report card comment). Mark was an "extremely responsible, motivated, hard-working, and wellmannered student" who displayed a "positive attitude and keen interest in [reading]" (Tracy, Term 1 report card comment). Mark was also encouraged by his teacher to "further challenge himself in reading and continue to motivate and guide others" (Tracy, Term 1 report card comment).

It should be emphasized that although three of the eight student participants were identified by their teachers as "struggling low-achievers with attention-deficit/hyperactivity problems" based on standardized assessment scores and classroom observations (Debra, teacher, Field notes, January 13, 2009; Jessica, teacher, Field notes, January 28, 2009; Tracy, teacher, Field notes, March 10, 2009), they were not formally identified as having learning difficulties or behaviour disorders within their school system. However, all three participants received additional support from the Reading Recovery school team.

\section{Research Design}

In order to develop the story as it is experienced by participants, and to more fully understand the nature of children's reading experiences, qualitative data were gathered from four perspectives: the researcher as an observer, the grade 1 student participants, their teachers, and their parents. The primary means of data collection consisted of: (a) participant observations during regular classroom reading instruction and online eBook reading sessions (recorded as field notes); (b) questionnaires; (c) transcriptions from individual, semi-structured teacher interviews; and (d) reading assessments such as provincial report card data. It is important to note that the monthly classroom observation sessions and online reading sessions represent the total number of observations that occurred with each student participant. 


\section{The Online eBooks}

The online eBooks (see Figure 1 for a sample screenshot) used in this study were found on the Listening and Reading Comprehension link on the Childtopia ${ }^{\mathrm{TM}}$ (Childtopia SL, 2008) website (www.childtopia.com), which was specifically designed for children between infancy and 10 years old. The storybooks used in the online reading sessions were similar in length (comprising between 10-15 pages of text and ranged from 200-300 words per page), characterization, complexity and illustrations. Childtopia ${ }^{\mathrm{TM}}$ was chosen for this study because it was freely accessible to the researcher.

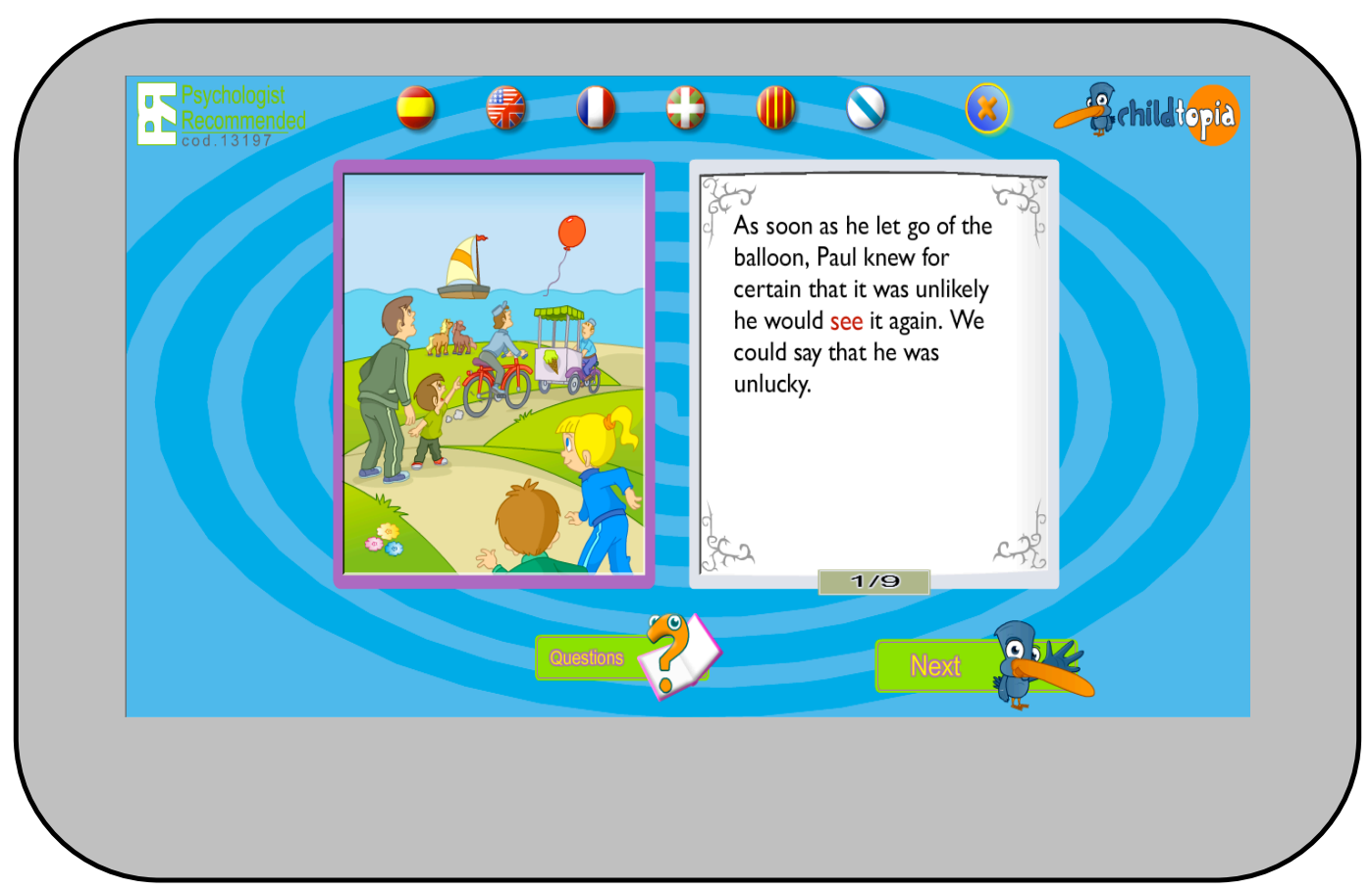

Figure 1: Example of online eBook from ChildTopia ${ }^{\mathrm{TM}}$

Each story was also accompanied by a set of 10 comprehension questions that were mainly factual and read aloud using the same female narrator's voice (see Figure 2 for a sample screenshot). Independent readers, however, had the option of turning off the audio narration and read the stories and questions to themselves. 


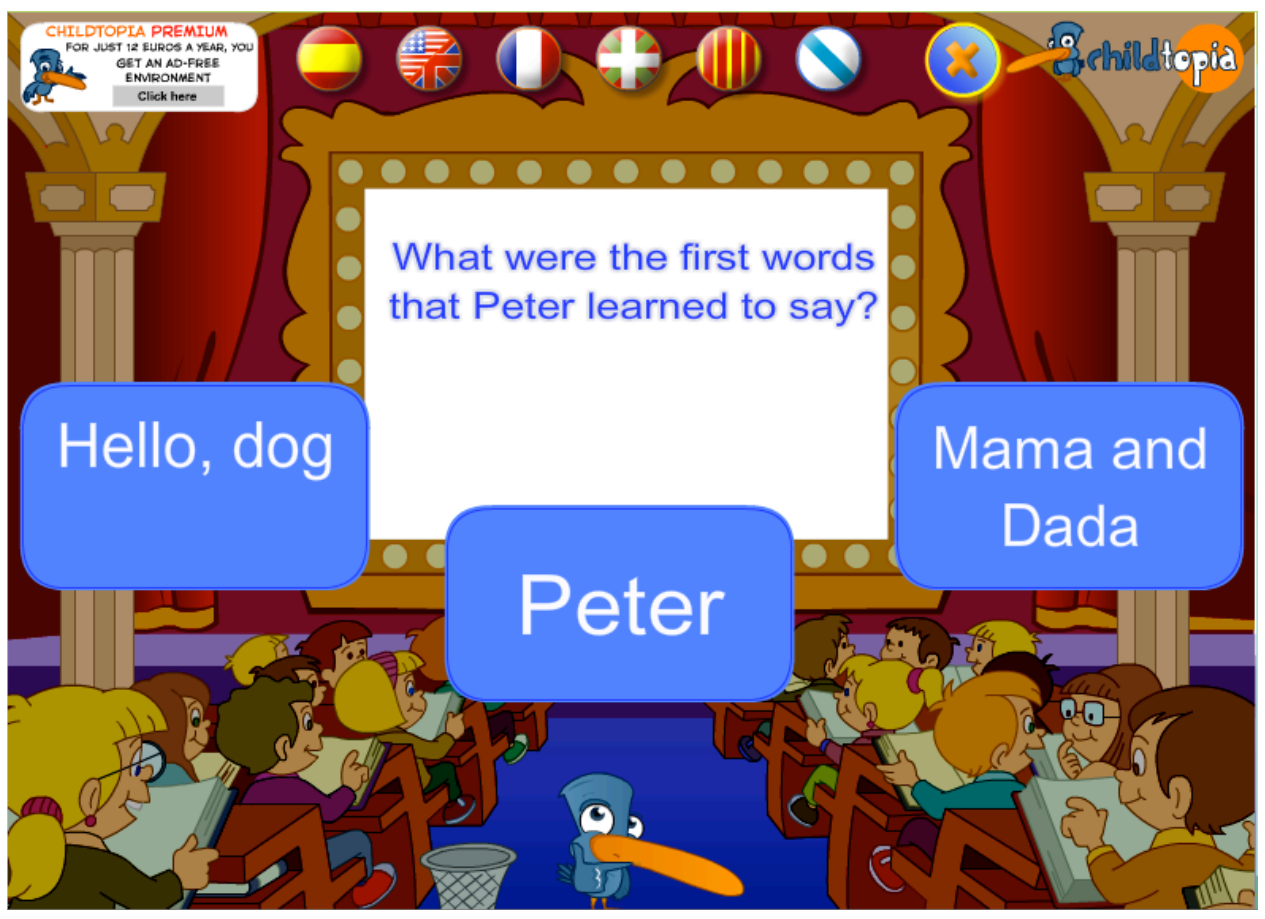

Figure 2: Example of post-reading comprehension question from ChildTopiaTM

\section{Instruments}

\section{Classroom observations}

Each grade 1 classroom was observed, and detailed observations of the eight target participants were taken by the researcher during regularly scheduled literacy blocks. Sociocultural studies of reading engagement in classroom contexts often focus on time-on-task behaviours, which are observable manifestations of motivation. In fact, some researchers have successfully captured some behavioural and active features of reading engagement (on-task and off-task) in classroom through direct observation (Marks, 2000). Thus, the researcher decided to use direct observations of participants during classroom-based reading instruction and activities to confirm students', parents', and teachers' reported levels of engagement in reading tasks. On-task behaviours were operationalized in classroom settings as visual orientation to a required stimulus (e.g., book or worksheet). Conversely, inattention or off-task behaviour is inferred by frequent shifts in activity and behaviour that is not task-related (Marks, 2000).

\section{Online eBook reading observations}

The computer sessions were held individually in the school library's computer lab during the participant's recess and/or lunch hour so that he or she did not lose any classroom instructional time. During the online reading sessions, the participants worked individually next to the researcher and wore headphones to reduce any auditory distractions. Field notes were used to record specific behaviours and level of engagement of every child participant during the digital reading sessions, including any comments made by participants on elements of illustrations, features, and functions of print on the page, as well as any extraneous comments, questions, and issues related to the child participants' attention, posture, and eye gaze. A child's high level of 
engagement during both the read-aloud and post-reading activity on the computer was defined as those times when the student was always attending to the computer screen, by reading aloud or along with the story, clicking the mouse to the "next" page in the story or question, making comments to the observer about the story read or questions asked, using other positive, task/goal-oriented nonverbal behaviours (e.g., smiling when the computer told the child "Well Done!" after answering a question correctly, or eagerly going back to the question and reattempting the question after the computer told the child, "Oops, try again"). Conversely, a child's low level of engagement during both the read-aloud and post-reading activity on the computer was defined as those times when the student was never attending to the computer screen, not reading along with the story or answering the questions; if students had their eyes closed or oriented toward another object in the room rather than the computer screen, then they were also considered off-task. During the postreading activity, a low level of student engagement was defined as those times when the student never changed his/her facial expressions when receiving a correct or incorrect response to a question (e.g., when the computer told the child, "Well Done!" or "Oops, try again" after he/she clicked on his/her answer).

\section{My motivation to read questionnaire-child version (pre-program and post-program)}

An adapted version of the Motivation to Read Profile (Gambrell et al., 1996) was utilized at the beginning (September) and end of this study (April) in order to develop a more in-depth understanding of and authentic insights on grade 1 students' experiences and attitudes toward digital reading. The following questions that pertained to students' experiences with and attitudes toward online computing technologies, and more specifically, online eBooks were added: "(1) Do you use the Internet at home? At school? (2) What do you do on the Internet at home? At school? (3) Have you ever used the Internet for reading? If yes, what do you read on the Internet? (4) If you had to choose between reading a hardcover book, reading an electronic book, or not reading at all, which would you choose? Why?" In addition, the following questions were added on the post-program My Motivation to Read Questionnaire \#2: "(1) Have you visited the website we used to read and answer questions since you started this project with me? (2) If yes, how many times did you visit the website? Why did you visit the website? If no, why didn't you visit the website? (3) What did you enjoy most/least about reading the stories on the computer? (4) What did you enjoy most/least about the reading activities you did after reading the stories on the computer?"

Content validity was enhanced by having this instrument independently assessed by two grade 1 teachers as well as the researcher's Faculty Advisor who teaches courses in educational psychology, literacy assessment and evaluation.

\section{My child's motivation to read questionnaire-parent version (pre-program and post-program)}

Parents of the eight student participants were asked to complete and return two versions of the My Child's Motivation to Read Questionnaire before (September) and after (April) the study. This instrument was constructed to parallel the content and format of the student version so that measures between parents and children would be comparable for data analysis. The questionnaires asked parents to provide their perception about their child's level of enjoyment derived from participating in various reading activities. Parent respondents were also invited to write comments about their child's involvement in this study, including any changes they may have seen in their child's motivation toward reading (especially online eBooks). 


\section{Teacher interviews (post-program)}

Each teacher was interviewed individually by the researcher in the school library during recess (approximately 15 minutes in length) at the end of this study (April). These semi-structured interviews were audio taped, transcribed, and member checked. Teachers were asked to describe any changes they informally observed in terms of the participants' reading behaviours and intrinsic motivations, especially towards computer-based online reading; for example, teachers were asked whether participants had been asking to use the classroom computers to access the Internet (for reading) more frequently. In addition to this type of question, teachers were asked to share their views on the integration and significance of the Internet, and more specifically, online eBooks, as a tool to enrich first grade students' classroom reading instruction (compared to printbased reading instruction).

\section{Procedure}

The following section will describe preprogram, interim-program and postprogram activities and data collection procedures that occurred across the school year.

\section{Pre-program Activities}

In addition to providing written consent for their children to participate in this study, all of the parents completed and returned the My Child's Motivation to Read Questionnaire \#1 to the researcher by late September. Throughout the first two terms of the school year, a copy of the participants' provincial report card grades were obtained from the participants' grade 1 teachers.

\section{Interim-program Activities}

Eighteen regularly scheduled classroom observation sessions were conducted on a weekly basis during the 120-minute morning literacy blocks beginning in September and continuing through April.

The researcher conducted the researcher-developed My Motivation to Read Questionnaire \#1 with all eight student participants in late September. This questionnaire was individually administered (on a one-on-one basis) in the school library during the student participant's recess period. The time for each questionnaire varied due to the age and ability levels of the sample, but the average time it took for participants to complete the questionnaire was 25 minutes.

Ten 25-minute online reading sessions over a 15-week period from November through April were held individually in the school library's computer lab during the participant's recess and/or lunch hour so that he or she did not lose any classroom instructional time. During the ten online reading sessions, the participants worked individually next to the researcher and wore headphones to reduce any auditory distractions. A familiarization session with the computer was held prior to the participants' first online reading session in mid-November. The online reading sessions and classroom observation sessions occurred on the same day for each individual participant in order to limit any confounding maturational factors and to compare participants' behaviour and interactions during reading instruction in these two settings (e.g., digital environment versus print-based classroom environment). The typical interval between each online reading session was one week. The participants generally completed one storybook per session; however, as will be discussed further on, technical difficulties were encountered during 
some of the sessions, resulting in the student being unable to either read the entire storybook or complete the post reading activities. The observations and data collection was suspended and reconvened either later on that day or the following day. Student participants generally completed two storybooks per session. The average total time it took participants to read one of these storybooks and complete the post-reading activity was ten minutes. The average total time participants spent answering the comprehension questions after reading their self-selected eBook was 15 minutes, but this varied widely depending on the ability level of the participant. Observational data from every online eBook reading session was recorded in field notes, with each session lasting approximately 25 minutes (from November through April).

\section{Postprogram Activities}

Similar to the administration of the previous questionnaire, the final My Motivation to Read Questionnaire \#2 was individually administered in the school library during the child participants' recess or lunch hour period in April.

Approximately one week after the classroom-based observations and online reading sessions were complete in mid-April, the researcher sent home to parents of participants a Letter of Appreciation for allowing their son/daughter to participate in this study as well as the My Child's Motivation to Read Questionnaire \#2. The parent questionnaires were completed and returned to the classroom teacher in late April.

Individual teacher interviews were conducted at the end of this study in April. Each interview was conducted in the school library during recess and lasted approximately 15 minutes in length.

\section{Data Analysis}

Interviews, field notes, and questionnaires were transcribed and coded using a word-processing program (Microsoft Word). Each dataset was organized and coded according to the participants' homeroom teacher (using single-letter identifiers A-D) and school type (School 1 and School 2). In an attempt to gain a sense of the whole, the researcher listened to the recorded interviews and questionnaires, as well as read and reread the field notes and transcripts a few times, which increased the researcher's understanding and enabled her to present what has been discovered to others. After several readings of the data files, the researcher worked on linking the data to this study's research question. Here, the researcher highlighted interesting sections, certain words, phrases, patterns of behaviour, and occurrences that repeated themselves, thus segmenting pieces that stood by themselves. The researcher completed her initial open coding of data by creating tables. Commonalities and differences among student, teacher, and parent responses, experiences, and behaviours were then identified and accomplished using axial coding (Creswell, 2010).

Verification and authenticity (Creswell, 2010) were established by utilizing multiple sources of data and collection strategies over an extensive period of time (Creswell, 2010). The interview data with the four grade 1 teacher participants were verified through the process of member checking. All of the teachers received a hard copy of their interview transcriptions as well as a framework of the themes that emerged across the teacher narratives, in order to validate the researcher's findings and interpretations of the data (Creswell, 2010). In order to establish the credibility of the conclusions and findings, peer debriefing was also used. The peer debriefer, the 
researcher's Faculty Advisor, reviewed data samples, and generally provided a sounding board for the researcher's ideas, questions, and conclusions in order to confirm or disconfirm emergent themes as logical and proper.

\section{Summary of Findings}

\section{Theme 1: Students' Pre-Program Reading Experiences}

As evidenced by classroom observations and reading levels, the responses of Jaclyn, James, and Christina reflected their low reading achievement and off-task, unmotivated behaviours during classroom reading times. Unlike the other five participants, these three participants frequently engaged in off-task behaviour during reading-related tasks. James, Jaclyn and Christina had difficulty focusing independently on printed material for a sustained period of time, and often resorted to fidgety, off-task or disruptive behaviours (i.e., disrupting their neighbours) during their guided, small-group reading sessions with their peers to avoid looking incompetent or to hide their uncertainty about a word. Unlike the independent reading behaviours of the other four participants, James, Jaclyn, Sally, and Christina often stopped reading, did not attempt to independently sound out or guess the word, and instead waited for their teachers' assistance. Consistent with previous findings (e.g., Burns, 2006), guided reading was extremely helpful to these students only when the teachers provided undivided attention and one-on-one instruction. The "levels of attention, reading productivity, and accuracy improved dramatically" for James, Jaclyn, and Christina when their teachers provided undivided attention and on-one-on instruction (Debra, teacher, notes, September 22, 2008; Tracy, teacher, Field notes, September 30, 2008; Jessica, teacher, Field notes, October 17, 2008).

Again, classroom observations revealed that during independent reading times, Jaclyn, James, and Christina all self-selected books that were either too challenging for them, as they quickly flipped through the pages and focused mainly on the pictures rather than the words on the page, or selected the same easy, low-level books (Level A) that were below their actual reading level. These participants gave up easily, especially when they were challenged with an unfamiliar word. During one observation session, Jaclyn attempted to read a new fiction picture book that was at her reading level, but stopped reading after the first page and flatly stated, "I don't want to read anymore, it's too hard" (Tracy, teacher, Field notes, October 21, 2008). Similarly, when Christina was stuck on a word, she did not try to pronounce the word, but quickly closed the book and mumbled "Whatever" (Jessica, teacher, Field notes, October 1, 2008).

Conversely, the remaining five participants always tended to appear more confident in their reading abilities, as they often read aloud more fluently and naturally, with expression and excitement. According to the teacher comments on the Term 2 report cards for Sarah, Mark, Christopher, and John, they have all "demonstrated strong independent reading skills" (Tracy, teacher, Term 2 report card comment; Jessica, Term 2 report card comment; Veronica, teacher, Term 2 report card comment). Sally, Mark, Sarah, Christopher, and John always worked diligently, were on task, used their time efficiently, and rarely asked for teacher assistance, as confirmed by their Term 1 report card comments, "they work well without supervision, obtain information independently and persist with challenging tasks" (Jessica, teacher, Term 2 report card comment; Tracy, teacher, Term 2 report card comment). 
The classroom observation data showed evidence of James', Jaclyn's, and Christina's passive engagement and negative attitudes toward reading, which were also reflected in their first questionnaire responses. For example, the first question posed to both students and parents on their questionnaires related to the importance they attached to (their child) reading well. The findings revealed that, with the exception of James, Christina, and Jaclyn, the remaining five student participants and all of the parents felt it was very important (for their child) to read well. The responses of Jaclyn, Christina, and James on the Importance of Reading subscales pointed to the fact that reading was not viewed as an activity of high priority for them. Similarly, when they were asked, "How often do you read for fun on your own time?" these same three participants indicated that they never or hardly ever engaged in reading for non-academic purposes and would rather partake in other leisure activities.

The student participants reported their frequency of Internet use at home and at school. Interestingly, while all of the child participants reported in their first questionnaire that they never or hardly ever used the computer and Internet at school, they tended to spend more time on Internet-related activities at home. The majority of participants used their home computers for playing (CD-ROM) games such as My Little Pony, Dora the Explorer, Freddie the Fish, and various computer-sports games (e.g., golf, bowling and racing; Child Questionnaire 1). At school, the participants mostly used the computer for drill-and-practice phonics instruction.

\section{Theme 2: Students' Online eBook Reading Experiences}

Observations of the eight student participants during the eBook reading sessions indicated that they were always on task and highly engaged. Interestingly, during their eBook reading sessions, Christopher, Sally, Mark, John, and Sarah all displayed similar behaviours as observed during traditional classroom read-aloud and reading instruction. Specifically, these students were never distracted by surrounding noises and their eyes were always oriented toward the computer screen. Further, Sarah and Mark were very confident when answering questions, and often made text-to-self connections while reading.

In contrast to the researcher's classroom observational data, Christina, Jaclyn, and James appeared to be paying attention most of the time as the story was read to them. In particular, Christina's enthusiasm for online storybook reading was evident when she found a story that sparked her interest: "I want to read this one!" (Field Notes, Christina, January 21, 2009). When her eyes were oriented toward the computer screen, Christina appeared very focused and engaged at the beginning of the story (Field Notes, Christina, January 21, 2009). For example, when the first word-attack question appeared on the screen, Christina immediately sat up straighter, closer to the edge of her seat, and moved her head closer to the computer screen so as not to miss anything. After she correctly answered the first "Word Scramble" question, Christina excitedly yelled, "I like this part!" with a huge smile on her face (Field Notes, Christina, January 21, 2009).

Dissimilar to observations of Jaclyn's off-task behaviours during regular classroom reading instruction and paper and pencil activities, Jaclyn displayed on-task behaviours and blossomed when she worked with this technological tool. During Jaclyn's participation in the online storybook reading and postreading activities, it was evident that the digital children's literature program and computer-based reading activities sparked Jaclyn's interest and tapped a hidden skill. During the read-aloud, Jaclyn was intently focused on the computer screen, particularly the 
animations, and always eagerly anticipated the forward button to "pop-up" and chime when she had to turn the page. Jaclyn was never fidgety, getting out of her seat, or playing with small objects while she was reading or answering questions, which occurred relatively frequently in class. Unlike her classroom behaviours during reading activities, Jaclyn successfully demonstrated her listening comprehension and word-attack skills during the computer-based postreading activities. When she received immediate praise from the computer, Jaclyn always smiled proudly and exclaimed in a singing voice "I got it right! Yay!" (Field Notes, Jaclyn). Jaclyn occasionally attributed her success to external, unstable causes of luck. Over time, Jaclyn slowly began to attribute her success to internal factors, which was evident when she stated, 'I'm really good at this!" (Field Notes, Jaclyn, February 2, 2009). When she provided an incorrect response, Jaclyn was determined to go back and reattempt the question and would insist on clicking the sound icons to have the words and questions read aloud to her again.

While James exhibited very similar off-task behaviours as Jaclyn during his regular classroom reading instruction and seatwork activities, he was also found to be highly involved during the online storybook reading and computer-based reading activities without any assistance. When the collection of storybooks available on the Childtopia ${ }^{\mathrm{TM}}$ website appeared on the computer screen, James would always rapidly move his mouse over each storybook icon to hear the tapping sounds that played simultaneously. The introduction of the digital children's literature program was followed by an immediate decrease in the rate of James's off-task behaviour and led to an increased level of engagement in the online storybook read-aloud. Similar to Jaclyn, James also made several comments, text-to-self connections, and interpretive observations relevant to the characters or objects in the story (e.g., "Look at his arm!" "Did you notice that fly was sleeping?" and "Hey, that's my name too -James!"; Field Notes, James). In contrast to his behaviours during regular reading instruction or seatwork activities in his classroom, James was highly engaged during his participation in the post reading activities and rarely needed reminders to stay on task.

Interestingly, during classroom observations, and on more than one occasion, James would ask Debra when he would be able to work with the researcher, to which Debra replied, "When you are finished all of your seatwork" (Debra, teacher, Field Notes, January 8, 2009). Debra used this incentive effectively to keep James's behaviour under control while simultaneously increasing his motivation level through his computer usage. James successfully completed all of his seatwork tasks in a very short time period (which was seldom observed).

\section{Theme 3: Students' Post-Program Reading Experiences}

In particular, three students (Christina, Jaclyn, and James) did not appear intrinsically motivated to read or interested in improving their reading skills prior to their involvement in this study. It was a different scenario for them after their involvement in this program, as they always looked forward to working on the computer during the reading sessions. On a positive note, according to the students' and their parents' final questionnaire responses, Jaclyn, James, and Christina, in addition to three other student participants, reportedly visited the Childtopia ${ }^{\mathrm{TM}}$ website at home, with two of them engaging in online storybook reading on more than five occasions (Child Questionnaire 2). In fact, although Mark previously reported that he did not really enjoy the eBook reading experience, he later indicated that he visited and "read the storybooks and answered the questions on the website four times" (Child Questionnaire 2). Christopher's enthusiasm and interest in online reading was also evident when he stated at the end of one 
session, "I am going to go home tonight and read this story again!" (Field notes, Christopher, March 4, 2009). According to all four teachers, when provided with free-choice center time, six of the student participants also gravitated to the computer center and asked to use the computer more since their involvement in this study.

According to their final questionnaire responses, the participants' cited reasons for enjoying the digital children's literature program (e.g., "the moving pictures," "the big red words that helped me learn new words and read along," "I could choose which book I want to read," and "I can have a book read to me without any help") highlight that the program's features engaged student participants in learning to read (Clarfield \& Stoner, 2005; Ota \& DuPaul, 2002). Five student participants believed that web-based eBook reading environments were easier to read and listen to in comparison with print-based texts. Students also talked about text interactivity. For example, Mark, one of the student participants, cited the following reason for selecting the former type of reading material, "The words were highlighted in red, so it was easy to read along by myself and learn new words" (Child Questionnaire 2). These same respondents claimed that reading online storybooks helped them learn more word wall words as compared to traditional hardcover books. In line with this, Sarah preferred to read electronically because she "could have a book read to her without any help" (Child Questionnaire 2).

With respect to their preference for completing reading online storybooks, the same group of participants still really enjoyed this type of reading material. In addition to these students, and unlike their first questionnaire responses, John, James, and Jaclyn no longer chose to read conventional texts, and were now very happy and preferred to read electronic online texts instead.

Consistent with Skinner (1969) and Thorndike (1932), students need to receive immediate feedback in order to make corrective modifications and guide subsequent responses. The computer-based reading activities in this study incorporated an immediate feedback strategy (Epstein \& Brosvic, 2002; Epstein et al., 2002). Christopher's comment highlights this: "If I get a wrong answer [on the Childtopia website], then I fix my answers right away and do better" (Child Questionnaire 3). Similarly, students were asked, "Do you like knowing if you got a right or wrong answer quickly?" and all of the participants answered yes in response to this question.

Christopher noted that he had a lack of autonomy and choice during reading instruction and stated: "My teacher [Veronica] doesn't let me choose which book she reads to me, but I get to pick the book I read on the Childtopia ${ }^{\mathrm{TM}}$ website" (Child Questionnaire 2). On the contrary, students were also given the choice of which online storybook they would have read to them, and they made their own decisions as to which page of text they would read or have read to them again. Debra and Jessica also stated, "They do have more choice and freedom on a computer" (Debra, teacher, Interview 1); "read-alouds in the classroom are more teacher directed, because the teachers are picking the book" (Jessica, teacher, Interview 1). In support of this, seven student respondents felt that online storybook reading provided them with more control and choice relative to traditional reading materials.

Based on their final questionnaire responses to the question, "How important is it for you to read well?" all of the student participants, including previously unmotivated students such as Christina, Jaclyn, and James, placed a higher value and importance on learning to read well by 
the end of their computer program involvement. In their first questionnaires, Christopher, Sally, John, James, Jaclyn, and Sarah rated their feelings toward completing computer-based reading activities less than positively; however, they all reported increased positive feelings about engaging in such activities at the end of this study.

Since "[individualization is not always possible] given the constraints on time in most classrooms" (Debra, teacher, Interview 1), the teachers in this study believed that online talking storybooks such as the ones available on the Childtopia ${ }^{\mathrm{TM}}$ website could be effectively used as an adjunct to traditional read-aloud, especially in the grade 1 classroom for struggling, beginning readers who require one-on-one attention (e.g., Veronica, teacher, Interview 1).

\section{Discussion}

With the goal to understand grade 1 students' experiences with and attitudes toward reading digital texts in a sociocultural context, this investigation was undertaken as a general qualitative study (Creswell, 2003). Classroom observations revealed that five student participants exhibited diligent, motivated, on-task behaviours during reading, while the exact opposite behaviour patterns were observed in the other three student participants. Conversely, Jaclyn's, James's, and Christina's reading competence beliefs were deflated, and they frequently used maladaptive coping strategies such as task avoidance (Covington, 2000; Miller \& Meece, 1999; OnatsuArvilommi et al., 2002; Salonen et al., 1998; Westen, 1996; Wigfield \& Guthrie, 1997; Woolfolk-Hoy, 2005). These student participants' behaviours matched their attitudes toward completing such print-based worksheets after reading a story but not toward completing computer-based reading activities.

The findings of this study contribute to the growing evidence base on the positive motivational effects of computer-assisted reading instruction on students, especially those who had reading and behavioural difficulties during their classroom reading instruction, such as Jaclyn, James, and Christina. Their perceived enjoyment and fascination with online storybook reading might continue to be used as incentive to foster these students' reading motivation suggest that computer-based reading instruction resulted in increased sustained attention and decreased offtask behaviour for the three "struggling" student participants who were hyperactive and inattentive during the components of their classroom's beginning reading instruction. The offtask behaviours typically displayed by Jaclyn, James, and Christina during sustained classroom reading instruction were not observed during their computer sessions. The present results were similar to those of Ota and DuPaul (2002), and Clarfield and Stoner (2005), as these student participants' involvement in this program appeared to provide them with individualized, highly engaging instruction with high rates of success and reinforcement. These three students were highly engaged, attentive, and involved during the online storybook reading and the multimediabased reading activities. For some grade 1 student participants, such extrinsic motivators as individual immediate feedback (in the form of positive reinforcement) and decreased rates of social comparison with peers may have a positive influence on their perceived self-efficacy and motivation. These three participants, who had a maladaptive attribution style and usually attributed their computer program successes to unstable, external factors such as luck ("I guessed that answer"), later began to use more adaptive attribution styles with positive self-talk ("I am really good at this!" and "I remembered this part of the story") towards the end of this study. 
It is also worth noting that these three participants, in addition to two other participants, reportedly increased the frequency of computer and Internet usage at home. Aside from online game playing, these student participants claimed to read more eBooks at home and visited the same Internet website used in this study's program sessions for online storybook reading as well as for completing the site's post reading activities. This supports Deci and Ryan's (1985) motivation theory as these participants were intrinsically motivated to actively engage in these technological tools during their free time at home (McCarrick \& Xiaoming, 2007). In fact, since their involvement in this study, seven of the eight participants rated more positive feelings toward digital reading instruction (than before the program), and three student participants (John, Jaclyn, and James) who originally preferred print-based worksheets, now preferred online storybook reading and completing reading activities on the computer. Six student participants (Jaclyn, James, John, Christina, Sarah, and Christopher) also asked their teachers to use this technological tool more since their involvement in this study.

All of the students were actively involved in their selecting online storybook read-alouds during their program sessions. According to the parent and student questionnaire responses, all of the participants were happier when they were able to choose the kind of reading material they read rather than have it chosen for them. Reflecting on their digital reading, the motivational qualities of self-determination, choice, and stimulation were some of the student participants' cited reasons for enjoying this program. That is, student participants' greater perceived control in their online book reading choices may have contributed to their increased interest in the content domain and motivation to read.

In opposition to the immediate oral feedback of their responses during the read-aloud, student participants experienced delayed feedback when they completed postreading comprehension print-based activity worksheets and often waited a few days or even weeks to find out whether their responses were correct. By contrast, the multimedia-based postreading activities enabled student participants to receive instantaneous feedback. The rapidity of feedback was one of the program's strongest advantages (Clarfield \& Stoner, 2005) and perhaps part of the reason for the student participants' perceived enjoyment of this activity.

The motivational qualities of choice, control, interest, and involvement were apparent with the student participants' visual eye gaze patterns during their interactions with hardcover books as well as with the computer programs. Observational data showed that the majority of student participants focused on the animated moving pictures first but then drew their attention to the highlighted text. It appeared that the word-by-word matching and 3-D animated features helped to capture all of the participants' attention (including the struggling readers), assist in the learning of new words, and sustain attentive listening during the entire read-aloud without being distracted or influenced by their peers or external stimuli. The participants' cited reasons for enjoying the digital children's literature program (e.g., "the moving pictures," "the big red words that helped me learn new words and read along," "I could choose which book I want to read," and "I can have a book read to me without any help") highlight that the program's features engaged student participants in learning to read (Clarfield \& Stoner, 2005; Ota \& DuPaul, 2002).

\section{Implications}

This study has revealed that alongside conventional reading, multimedia and online storybook reading may have positive motivational effects, particularly with those student participants who 
have not experienced success in reading. The digital children's literature program and post reading multimedia program exposed the eight grade 1 student participants to diverse and interactive versions of a read-aloud with follow-up reading activities. These findings have some implications for curricular practice.

Teachers can assess these different aspects of reading motivation by questioning students with an instrument like the researcher-developed My Motivation for Reading Questionnaire at the beginning of the school year and several times throughout the school year, so that changes in the child's reading motivations, attitudes, and interests can be documented over time. This questionnaire may increase teachers' awareness of their students' reading attitudes, challenges, and interests. The information derived may help teachers become more knowledgeable about effective and motivational reading instruction practices that meet the diverse needs of their students and take into account the prior knowledge and experiences each child brings to the classroom. Careful scrutiny of the responses, coupled with teacher observations of student behaviours in various classroom reading contexts, can help teachers plan for meaningful, individualized reading instruction that will support students in becoming highly motivated readers.

Another consideration for practice is to capitalize on immediate feedback student participants received from their computer program sessions. Activities that offer the greatest potential for student enjoyment are those that allow students not only to respond actively but also to get immediate feedback that they can use to guide subsequent responses (Brophy, 2004; Skinner, 1969; Thorndike, 1932). Automatic feedback features are also built into many educational games and computerized learning systems (Malone \& Lepper, 1987). Similar to the findings in Ota and DuPaul (2002) as well as Acevedo-Polakovich et al.'s (2007) study, this feedback feature was an important reason for the student participants' perceived enjoyment of the researcher-developed multimedia-based reading activities. Unlike classroom practices after a reading lesson, within seconds the student participants quickly discovered and corrected their misunderstandings after they listened to the computer repeat the question and possible answers again.

Of particular importance, the computerized reading activities in a game format increased active engagement and performance but decreased James's, Jaclyn's, and Christina's off-task behaviours. These students had difficulties beginning and following through on print-based reading tasks and typically displayed attentional difficulties during their regular classroom reading instruction. It was observed that these students were eager to receive and respond to immediate feedback when learning something for the first time; whereas in their classrooms, they were much less enthused about the prospect of going back to try to relearn something that "they did already" (Brophy, 2004). In sum, for reading competence to occur, "students need to be provided with immediate feedback about their gains in knowledge and general reading progress" (Gaskins, 2005, p.118). Aside from using computer-assisted reading instruction such as the digital children's literature program and postreading multimedia program, teachers could also use strategies to maximize positive interaction with their students like Jaclyn, James, and Christina and minimize opportunities for disruptive behaviour.

The results from this study are consistent with those of de Jong and Bus (2002) as well as Blum et al. (2008), who found that animations and 3D features further enhanced the student participants' engagement and motivation to listen to and understand online stories as well as successfully complete reading activities. Based on observations and participant questionnaire 
responses, the animated, 3D features embedded into the online reading program also captured the grade 1 students' attention, which may have motivated them to increase their effort and participation during the program sessions. It is also important to note that most of these gamelike features involve presenting intellectual challenges and are more effective in promoting student motivation to learn than are competitive games that emphasize speed in supplying memorized facts rather than integration or application of learning (Brophy, 2004).

\section{Limitations and Future Research}

The present qualitative study was designed to gain a deeper understanding of the nature of and attitudes toward conventional and digital reading experiences among grade 1 students, their parents, and teachers. Although the current results are promising, several limitations and implications for further research in this area are recommended.

First, technical difficulties experienced during the online reading sessions should be taken into serious consideration when conducting future Internet-mediated research, as they presented the greatest challenge in this study. On numerous occasions, observations and data collection were either suspended and reconvened at a later time or the programs were restarted during that session when there were technical problems. Some of these problems included glitches in the Childtopia $^{\mathrm{TM}}$ website, reduced Internet connection speed, computer freezing, hyperlinks, sound, and animations, all of which were a hindrance to and stalled participants' learning.

Consequently, this may have affected the participants' level of engagement and curtailed their enthusiasm for this type of learning environment. With any computer- and Internet-mediated research, it is virtually impossible to eliminate all technical difficulties. It is also important to remember that novelty effects do exist - their presence and influence on findings can no longer be ignored in research on computer-based learning. A research agenda for the future should include more longitudinal research addressing issues related to the long-term impact of the technology.

The results of this investigation suggest that the computerized reading program was effective in improving task engagement for three student participants with behavioural and reading difficulties. Thus, an investigation of the effectiveness of this digital children's literature program on reading skills and reading motivation with other early elementary school-age students who are formally identified as having learning difficulties or behaviour disorders, as well as English language learners experiencing academic and/or motivational problems in reading is warranted.

The outcomes that are reported here depend on a few informants rather than a representative sample of grade 1 students, teachers, and parents. A large-scale, nationally representative sample of grade 1 student participants, parents, and teachers would provide data at a system level and temper the confounding variables affecting children's reading attitudes toward and the effects of conventional and digital reading on their reading development and motivation.

\section{Conclusion}

The decrease in motivation to read across the elementary school years has stimulated concern about how students might be motivated to read and engage in literacy activities. This study has shown that online reading software, motivational aspects, and constructivist methods of 
instruction can promote reading motivation among beginning readers. Of particular importance was the effectiveness of these programs in decreasing off-task behaviours and increasing sustained levels of attention, competence and engagement for three students who had reading and attentional difficulties during the components of their classroom's reading program. Educators and parents are instrumental in helping their students to develop the new skills and strategies that are important in today's technological age. Overall, the findings from this study have shown that the digital children's literature program, although perhaps not an entirely satisfactory replacement for adults reading printed books to children, may nonetheless be a beneficial supplement to oral and print literacies for grade 1 students. These online reading programs may provide an opportunity for practice of skills that beginning readers learn from direct, systematic instruction in their classrooms, in a highly appealing and constructivist manner. 


\section{References}

Alexander, P. A., \& Jetton, T. L. (2003). Learning from traditional and alternative texts: New conceptualization for an information age. In A. Graesser, M. Gernsbacher, \& S. Goldman (Eds.), Handbook of discourse processes (pp. 199-241). Mahwah, NJ: Erlbaum.

Asselin, M. (2004). Supporting sustained engagements with texts. Teacher Librarian, 31(3), 5152.

Aunola, K., Nurmi, J., Niemi, N., Lerkkanen, M., \& Rasku-Puttonen, H. (2002). Developmental dynamics of achievement strategies, reading performance, and parental beliefs. Reading Research Quarterly, 37(3), 310-328.

Blok, H., Oostdam, R., Otter, M., \& Overmaat, M. (2002). Computer-assisted instruction in support of beginning reading instruction: A review. Review of Educational Research, 72(1), 101-130.

Brophy, J. (2004). Motivating students to learn (2 ${ }^{\text {nd }}$ ed.). Mahwah, NJ: Lawrence Erlbaum.

Bruner, J. (1960). The process of education. Cambridge: Harvard University Press.

Castek, J., Bevans-Mangelson, J., \& Goldstone, B. (2006). Reading adventures online: Five ways to introduce the new literacies of the Internet through children's literature. The Reading Teacher, 59(7), 714-728.

Chapman, J. W., \& Tunmer, W. E. (2003). Reading difficulties, reading-related self-perceptions, and strategies for overcoming negative self-beliefs. Reading and Writing Quarterly: Overcoming Reading Difficulties, 19(1), 5-24.

Chapman, J. W., Tunmer, W. E., Prochnow, J.E. (2000). Early reading-related skills and performance, reading self-concept and the development of academic self-concept: A longitudinal study. Journal of Educational Psychology, 92(1), 703-708.

Childtopia, S. L. (2008). Childtopia ${ }^{\mathrm{TM}}$. Retrieved from http://www.childtopia.com

Clark, C., \& Foster, A. (2005). Children's and young people's reading habits and preferences: The who, what, why, where and when. London: National Literacy Trust.

Covington, M. V. (2000). Goal theory, motivation, and school achievement: An integrative review. Annual Review of Psychology, 51(1), 171-190.

Creswell, J.W. (2010). Educational research: Planning, conducting, and evaluating quantitative and qualitative research ( $4^{\text {th }}$ Ed.). Boston, MA: Pearson Education.

Das, J. P., Schoman-Gates, K., \& Murphy, D. (1985). The development of intrinsic and extrinsic motivational orientation in normal and disabled readers. Journal of Psychoeducational Assessment, 4(1), 297-312. 
de Jong, M. T., \& Bus, A. (2002). Quality of book-reading matters for emergent readers: An experiment with the same book in a regular or electronic format. Journal of Educational Psychology, 94(1), 145-155.

Deci, E. L., \& Ryan, R. M. (1985). Intrinsic motivation and self-determination in human behavior. New York: Plenum.

Deci, E. L., Vallerand, R. J., Pelletier, L. G., \& Ryan, R. M. (1991). Motivation and education: The self-determination perspective. Educational Psychologist, 26(5), 326-346.

Dewey, J. (1916). Democracy and Education: An introduction to the philosophy of education. New York, NY: Free Press.

Eccles, J.S. (1983). Expectancies, values, and academic choice: Origins and changes. In J. Spence (Ed.), Achievement and achievement motivation. San Francisco: Freeman.

Epstein, M. L, \& Brosvic, G. M. (2002). Immediate feedback assessment technique:Multiplechoice test that "behaves" like an essay examination. Psychological Reports, 90(1), 226260 .

Epstein, M. L., Lazarus, A. D., Calvano, T. B., Marks, K. A., Hendel, R. A., Epstein, B. B., \& Brosvic, G. M. (2002). Immediate feedback assessment technique promotes learning and corrects inaccurate first responses. Psychological Record, 52(2), 187-201.

Flowerday, T., \& Schraw, G., (2000). Teacher beliefs about instructional choice: A phenomenological study. Journal of Educational Psychology, 92(2), 634-645.

Gambrell, L. B., Palmer, B. M., Codling, R. M., \& Mazzoni, S. A. (1996). Assessing motivation to read. The Reading Teacher, 49(7), 518-524.

Grimshaw, S., Dungworth, N., McKnight, C., \& Morris, A. (2007). Electronic books: Children's reading and comprehension. British Journal of Educational Technology, 38(4), 583-599.

Guthrie, J. T., \& Wigfield, A. (2000). Engagement and motivation in reading. In M. L. Kamil, P. B. Mosenthal, P. D. Pearson, \& R. Barr (Eds.), Handbook of reading research (pp. 403422). London: Lawrence Erlbaum Associates.

Hooper, S., \& Rieber, L. P. (1995). Teaching with technology. In A. C. Ornstein (Ed.), Teaching: Theory into practice, (pp. 154-170). Needham Heights, MA: Allyn and Bacon.

Koc, M. (2005). Individual learner differences in web-based learning environments: From cognitive, affective and social-cultural perspectives. Turkish Online Journal of Distance Education, 6(4), 12-22.

Korat, O., \& Shamir, A. (2006). Electronic books versus adult readers: Effects on children's emergent literacy as a function of social class. Journal of Computer Assisted Learning, 23(2), 248-259.

Krashen, S. (2009). Anything but reading. Knowledge Quest, 37(5), 18-25. 
Krashen, S., \& McQuillan, J. (2007). The case for late intervention: Once a good reader, always a good reader. Educational Leadership, 65(2), 68-73.

Krendl, K. A., \& Clark, G. (1994). The impact of computers on learning: Research on in-school and out-of-school settings. Journal of Computing in Higher Education, 5(2), 85-112.

Krendl, K. A., \& Lieberman, D. A. (1988). Computers and learning: A review of recent research. Journal of Educational Computing Research, 4(4), 367-389.

Kroll, L. R. (2004), Constructing constructivism: how student-teachers construct ideas of development, knowledge, learning, and teaching. Teachers and Teaching: Theory and Practice, 10(2), 199-221.

Labbo, L. D., \& Kuhn, M. R. (2000). Weaving chains of affect and cognition: A young child's understanding of CD-ROM talking books. Journal of Literacy Research, 32, 187-210.

Lefever-Davis, S., \& Pearman, C. (2005). Early readers and electronic texts: CD-ROM storybook features that influence reading behaviors. The Reading Teacher, 58(5), 4-10.

Leu, D. J. (2000). Teaching with the internet: Lessons from the classroom. Norwood, MA: Christopher-Gordon.

Linnenbrink, E. A., \& Pintrich, P.R. (2003). The role of self-efficacy beliefs in student engagement and learning in the classroom. Reading and Writing Quarterly, 19, 119-137.

Malloy, J.A., \& Gambrell, L.B. (2010). Essential Readings on Motivation. Newark, DE: International Reading Association.

Marks, H.M. (2000). Student engagement in instructional activity: Patterns in the elementary, middle, and high school years. American Educational Research Journal, 37, 153-184.

McCarrick, K., \& Xiaoming, L. (2007). Buried treasure: The impact of computer use on young children's social, cognitive, language development and motivation. AACE Journal, 15(1), 73-95.

McClenaghan, B. A; \& Ward, D. S. (1987). Health and physical education. In Charles A.Maher \& Susan G. Forman (Eds). A behavioural approach to education of children and youth (pp. 131-151). Hillsdale, NJ: Lawrence Erlbaum Association.

Metsala, J. L., Wigfield, A., \& McCann, A. D. (1997). Children's motivations for reading. The Reading Teacher, 50, 360-362.

Miller, D. (2009). The book whisperer: Awakening the inner reader in every child. San Francisco, CA: Jossey-Bass.

Ministry of Education of Ontario. (2003). Early reading strategy: The report of the expert panel on early reading in Ontario. Toronto: Author.

Moje, E. B., Young, J. P., Readence, J. E., \& Moore, D. W. (2000). Reinventing adolescent literacy for new times: Perennial and millennial issues. Journal of Adolescent \& Adult Literacy, 43(5), 400-410. 
Morgan, P. L., \& Sideridis, G. D. (2006). Contrasting the effectiveness of fluency interventions for students with or at risk for learning disabilities: A multilevel random coefficient modeling meta-analysis. Learning Disabilities Research \& Practice, 21, 19-210.

Morgolis, H., \& McCabe, P.P. (2004). Self-efficacy: A key to improving the motivation of struggling learners. The Clearing House, 77(6), 241-249.

Nelson, J. M., \& Manset-Williamson, G. (2006). The impact of explicit, self-regulatory reading comprehension strategy instruction on the reading-specific self-efficacy attributions, and affect of students with reading disabilities. Learning Disability Quarterly, 29, 213-230.

Onatsu-Arvilommi, T., Nurmi, J. E., \& Aunola, K. (2002). The development of achievement strategies and academic skills during the first year of primary school. Learning and Instruction, 12(5), 509-527.

Pearman, C. (2008). Independent reading of CD-ROM storybooks: Measuring comprehension with oral retellings. Reading Teacher, 61(8), 594-602.

Piaget, J. (1973). To understand is to invent: The future of education. New York: Grossman.

Piet, A. M., Kommers, S. G., \& Dunlap, J. C. (1996). Hypermedia learning environments: Instructional design and integration. Philadelphia: Lawrence Erlbaum Associates.

Plowman, L., \& Stephen, C. (2003) A 'benign addition'? Research on ICT and pre-school children. Journal of Computer Assisted Learning, 19(2), 149-164.

Randi, J., \& Corno, L. (2000). Teacher innovations in self-regulated learning. In M. Boeaerts, P. R. Pintrich, \& M. Zeidner (Eds.), Handbook of self-regulation (pp.651-685). San Diego: Academic Press.

Reinking, D., \& Watkins, J. (2000). A formative experiment investigating the use of multimedia book reviews to increase elementary students' independent reading. Athens, GA: National Reading Research Center.

Renninger, K. A. (2000). Individual interest and its implications for understanding intrinsic motivation. In C. Sansone \& J. M. Harackiewicz (Eds.), Intrinsic and extrinsic motivation: The search for optimal motivation and performance (pp. 375-407). New York: Academic.

Ryan, R. L., \& Deci, E. M. (2000). Self-determination theory and the facilitation of intrinsic motivation, social development, and well-being. American Psychologist, 55(2), 68-78.

Sandholtz, J., Ringstaff, C., \& Dwyer, D. (1997). Teaching with technology: Creating studentcentered classrooms. New York: Teachers College Press.

Scheiter, K., \& Gerjets, P. (2007). Learner control in hypermedia environments. Educational Psychology Review, 19(6), 285-307.

Scott, J. E. (1996). Self-efficacy: A key to literacy learning. Reading Horizons, 36, 195-213.

Shade, L.R. (2002, Autumn). Canadian kids online. Transition, 1-11. 
Sideridis, G. D., \& Scanlon, D. (2006). Motivational issues in learning disabilities. Learning Disability Quarterly, 29, 131-135.

Skinner, B. F. (1969). Contingencies of reinforcement: A theoretical analysis. Englewood Cliffs, NJ: Prentice Hall.

Strommen, L. T., \& Mates, B. F. (2004). Learning to love reading: Interviews with older children and teens. Journal of Adolescent \& Adult Literacy, 48, 188-200.

Thorndike, E. L. (1932). The fundamental of learning. New York, NY: Teachers College Press.

Turner, J. C. (1995). The influence of classroom contexts on young children's motivation for literacy. Reading Research Quarterly, 30(3), 410-441.

Unrau, N., \& Schlackman, J. (2006). Motivation and its relationship with reading achievement in an urban middle school. The Journal of Educational Research, 100(2), 81-101.

Valleley, R. J., \& Shriver, M. D. (2003). An examination of the effects of repeated readings with secondary students. Journal of Behavioral Education, 12, 55-76.

Valmont, W. J. (2000). What do teachers do in technology-rich classrooms? In S. B. Wepner, W. J. Valmont, \& R. Thurlow (Eds.), Linking literacy and technology: A guide for K-8 classrooms (pp. 160-202). Newark, DE: International Reading Association.

Van Kleeck, A. (2003). Research on book-sharing: Another critical look. In A. van Kleeck, S. A. Stahl, \& E. B. Bauer (Eds.), On reading books to children: Parents and teachers (pp. 1636). Mahwah, NJ: Lawrence Erlbaum.

Wepner, S.B., \& Ray, L.C. (2000). Using technology for reading development. In R. Thurlow, W.J. Valmont, \& S.B. Wepner (Eds.), Linking literacy and technology. Newark, DE: International Reading Association, Inc.

Wigfield, A., \& Guthrie, J. T. (1997). Relations of children's motivation for reading to the amount and breadth of their reading. Journal of Educational Psychology, 89(1), 420-432.

\section{Author}

Katia Ciampa is a PhD candidate and sessional instructor in the Teacher Education Department at Brock University. Her research interests focus on technology integration in $\mathrm{K}-8$ education, electronic books to support early literacy learning, and the development of Technological Pedagogical and Content Knowledge (TPACK) in K-8 teachers. Email: kc03ot@brocku.ca.

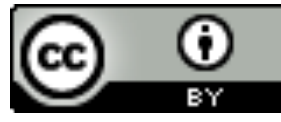

This work is licensed under a Creative Commons Attribution 3.0 License. 